\title{
UPAYA PENINGKATAN PEMAHAMAN SISWA PADA MATERI JAMUR MELALUI METODE PENEMUAN TERBIMBING DI SMA
}

\author{
Karomatusyafa'ah \\ SMA Negeri 3 Simpang Hilir, Kabupaten Kayong Utara Kalimantan Barat \\ Email: karomatusyafaah2015@gmail.com
}

\begin{abstract}
Abstrak
Penelitian tindakan kelas ini bertujuan untuk memperbaiki proses pembelajaran dan meningkatkan pemahaman siswa dengan menerapkan metode penemuan terbimbing pada materi Jamur siswa kelas X. Pembelajaran Biologi salah satunya dimaksudkan untuk meningkatkan pemahaman siswa terhadap materi Jamur. Bentuk penelitian yang digunakan adalah Penelitian Tindakan Kelas, yang dilaksanakan di kelas X MIA SMAN 3 Simpang Hilir Tahun Pelajaran 2018/2019 dengan siswa sebanyak 31 orang. Instrumen yang digunakan dalam penelitian ini berpa lembar observasi untuk mengukur kemampuan biologi dan soal tes untuk mengukur hasil pemahaman siswa.. Dari hasil analisis didapatkan bahwa (1)Penerapan metode penemuan terbimbing meningkatkan pemahaman materi jamur pada siswa kelas X MIA SMAN 3 Simpang Hilir. Peningkatan pemahaman siswa ditandai dengan peningkatan pengetahuan dalam setiap siklus. Siklus I rerata pengetahuan 67,32 dan siklus II menjadi 77,41. Peningkatan pemahaman juga ditandai dengan adanya prosentase ketuntasan pada siklus I 25,81\% menjadi 77,41\%, (2) Pembelajaran dengan metode penemuan terbimbing dalam kegiatan pembelajaran mampu meningkatkan kemampuan biologi. Dengan pembelajaran terbimbing kemampuan komunikasi, kerja sama, percaya diri dan empati meningkat secara signifikan, (3) Penerapan metode penemuan terbimbing berpengaruh positif, yaitu dapat meningkatkan minat dan motivasi belajar. Dengan demikian dapat disimpulkan bahwa penerapan metode penemuan terbimbing dapat meningkatkan pemahaman siswa
\end{abstract}

\section{Kata kunci: Pembelajaran Biologi, Pemahaman, Penemuan Terbimbing}

\section{PENDAHULUAN}

Pendidikan adalah usaha yang dilakukan dengan sengaja dan sistematis untuk memotivasi, membina, membantu, serta membimbing seseorang untuk mengembangkan segala potensinya sehingga mencapai kualitas diri yang lebih baik. Berhasil atau tidaknya suatu proses pendidikan sangat dipengaruhi oleh proses pembelajaran. Oleh karena itu sudah seharusnya menjadi tanggung jawab bersama untuk terus berusaha meningkatkan kualitas pendidikan. Guru sebagai pemegang kunci keberhasilan pembelajaran di kelas harus pandai memilih metode pembelajaran yang sesuai untuk menyampaikan materi pembelajaran agar diperoleh hasil belajar yang maksimal. Agar setiap pembelajaran mencapai KKM yang diinginkan.
Berdasarkan pengalaman penulis di lapangan, kegagalan dalam proses pembelajaran rata-rata dihadapi oleh siswa yang tidak memaksimalkan kemampuannya selama proses pembelajaran. Hal ini salah satunya disebabkan metode mengajar yang tidak memaksimalkan kemampuan siswa, diantaranya adalah metode ceramah. Sehingga nilai rata-rata ulangan harian biologi masih di bawak KKM yaitu 5,20.

Metode Penemuan Terbimbing ini memiliki keunggulan dan memiliki ketepatan dalam pembelajaran jamur untuk mencapai standar kompetensi dengan memahami hasil evaluasi usaha. Sangat memungkinkan strategi ini akan memberikan dampak yang positif dalam meningkatkan pemahaman siswa dalam mengikuti pembelajaran jamur. Metode Penemuan Terbimbing merupakan 
me-tode pembelajaran yang dapat mendorong siswa untuk melakukan aktifitas belajar secara aktif. Itulah sebabnya dalam pembelajaran dengan observasi untuk meningkatkan minat belajar siswa dalam materi jamur dengan menggunakan metode Penemuan Terbimbing. Diharapkan dengan penggunaan metode ini pembelajaran mencapai kriteria ketuntasan minimal, yaitu 72.

Penelitian ini bertujuan untuk mengetahui peningkatan pemahaman siswa pada materi Jamur dengan menggunakan metode pembelajaran Penemuan Terbimbing siswa kelas X SMA Negeri 3 Simpang Hilir. Dengan menggunakan metode Pembelajaran Penemuan Terbimbing, penelitian ini diharapkan meningkatkan kemampuan biologi. Belajar biologi bukan suatu hal yang membosankan dan menakutkan, melainkan sesuatu yang menyenangkan.

Penemuan adalah terjemahan dari discovery. Menurut Sund "discovery" adalah proses mental dimana siswa mampu mengasimilasikan sesuatu konsep atau prinsip. Proses mental tersebut ialah mengamati, mencerna, mengerti, menggolong-golongkan, membuat dugaan, menjelaskan, mengukur, membuat kesimpulan dan sebagainya (Roestiyah, 2001:20). Sedangkan menurut Jerome Bruner "penemuan adalah suatu proses, suatu jalan/cara dalam mendekati permasalahan bukannya suatu produk atau pengetahuan tertentu". Dengan demikian di dalam pandangan Bruner, belajar dengan penemuan adalah belajar untuk menemukan, dimana seorang siswa dihadapkan dengan suatu masalah atau situasi yang tampaknya ganjil sehingga siswa dapat mencari jalan pemecahan ( Markaban, 2006:9).

Model penemuan terbimbing menempatkan guru sebagai fasilitator. Guru membimbing siswa dimana ia perlukan. Dalam model ini, siswa di dorong untuk berpikir sendiri, menganalisis sendiri sehingga dapat menemukan prinsip umum berdasarkan bahan atau data yang telah disediakan guru. Model penemuan terbimbing adalah model pembelajaran penemuan yang dalam pelaksanaannya dilakukan oleh siswa berdasarkan petunjukpetunjuk guru. Petunjuk diberikan pada umumnya berupa pertanyaan membimbing (Ali, 2004:87).

Dengan penjelasan diatas model penemuan yang dipandu oleh guru ini kemudian dikembangkan dalam suatu model pembelajaran yang sering disebut model pembelajaran dengan penemuan terbimbing. Pembelajaran model ini dapat diselenggarakan secara individu dan kelompok. Model ini sangat bermanfaat untuk mata pelajaran Biologi karena sesuai dengan karakteristik biologi. Guru membimbing siswa jika diperlukan dan siswa didorong untuk berpikir sendiri sehingga dapat menemukan prinsip umum berdasarkan bahan yang disediakan oleh guru dan sampai seberapa jauh siswa dibimbing tergantung pada kemampuannya dan materi yang sedang dipelajari.

Peran guru dalam penemuan terbimbing sering dingkapkan dalam Lembar Kerja Siswa (LKS). LKS ini biasanya digunakan dalam memberikan bimbingan kepada siswa menemukan konsep atau prinsip. Perlu diingat bahwa model ini memerlukan waktu yang relatif banyak dalam pelaksanaannya, akan tetapi hasil belajar yang dicapainya tentu sebanding dengan waktu yang digunakan. Pengetahuan yang bar akan melekat lebih lama apabila siswa dilibatkan secara langsung dalam proses pemahaman dan mengkonstruksi sendiri konsep atau pengetahuan tersebut.

Menurut Markaban (2006:16) agar pelaksanaan model pembelajaran penemuan terbimbing ini berjalan efektif, beberapa langkah yang mesti ditempuh oleh guru Biologi adalah sebagai berikut: (1) Merumuskan masalah yang akan diberikan kepada siswa dengan data secukupnya. Perumusan ini harus jelas, hindari pertanyaan yang menimbulkan salah tafsir sehingga arah arah yang ditempuh siswa tidak salah; (2) Dari data yang diberikan guru, siswa menyusun, memproses, mengorganisir dan menganalisis data tersebut. Dalam hal ini, bimbingan ini sebaiknya mengarahkan siswa 
untuk melangkah kearah yang hendak dituju melalui pertanyaan-pertanyaan; (3) Siswa menyusun prakiraan dari hasil analisis yang dilakukan; (4) Bila dipandang perlu prakiraan yang telah dibuat oleh siswa tersebut diperiksa oleh guru. Hal ini penting dilakukan untuk meyakinkan prakiraan siswa, sehingga akan menuju arah yang hendak Memperhatikan langkah-langkah model pembelajaran penemuan terbimbing diatas dapat disampaikan kelebihan dan kekurangan yang dimilikinya. Kelebihan model pembelajaran terbimbing adalah: (1) Siswa dapat berpartisipasi aktif dalam pembelajaran yang disajikan, (2) Menumbuhkan sekaligus menanamkan sikap mencari menemuka, (3) Mendukung kemampuan problem solving siswa, (4) Memberikan wahan interaksi antar siswa, siswa dengan guru. Dengan demikian siswa terlatih berkomunikasi, (5) Lama membekas dalam ingatan siswa, karena siswa dilibatkan dalam proses menemukan. Sedangkan kekurangannya sebagai berikut:

\section{METODE PENELITIAN}

Penelitian tindakan kelas ini dilaksanakan pada mata pelajaran Biologi Tahun Pelajaran 2018/2019. Penelitian ini dilaksanakan di Kelas X MIPA SMAN 3 Simpang Hilir. Subyek penelitian ini adalah siswa Kelas $\mathrm{X}$ SMAN 3 Simpang Hilir sebanyak 30 siswa dicapai; (5) Apabila telah diperoleh kepastian tentang kebenaran konjektur, maka verbalitas konjektur sebaiknya diserahkan juga kepada siswa untuk menyususnnya, (3) Sesudah siswa menemukan apa yang dicari hendaknya guru menyediakan soal latihan atau soal tambahan untuk memeriksa apakah penemuan itu benar.

(1) Untuk materi tetentu, wakt yang tersita lebih lama, (2) Tidak semua siswa dapat mengikuti pelajaran dengan baik dengan cara ini. Dilapangan, beberapa siswa masih terbiasa dan mudah dimengerti dengan model ceramah. Berdasarkan pendahuluan diatas hipotesis penelitian tindakan kelas ini adalah Melalui metode penemuan terbimbing, pengetahuan siswa kelas $X$ SMAN 3 Simpang Hilir pada materi jamur dapat ditingkatkan. Penelitian ini dapat dikatakan berhasil apabila jumlah siswa kemampuannya mencapai KKM.

terdiri dari 12 laki-laki dan 19 siswa perempuan. Kondisi siswa kelas ini secara akademik memiliki kemampuan baik tetapi memiliki kelemahan antara lain keberanian mengemukakan pendapat, bekerja sama kurang berkembang.

Tabel 1. Pengamatan Aspek Kemampuan Biologi Siswa

\begin{tabular}{cccl}
\hline No & Indikator & & \multicolumn{1}{c}{ Deskriptor } \\
\hline 1. & Komunikasi & a. & Keberanian mengemukakan pendapat atau ide \\
& & b. & Mampu merespon dan menanggapi pertanyaan \\
& & c. & Mau bertanya dan menjawab pertanyaan \\
& & d. & Aktif dalam memberikan pendapat atau pertanyaan \\
\hline 2. & Kerja sama & a. & Bekerjasa sama dengan sesama anggota \\
& & b. & Berbagi tugas dengan sesama anggota \\
& & c. & Berpartisipasi aktif melakukan diskusi kelompok \\
& & d. & Berinteraksi dengan kelompok lain dalam belajar \\
\hline 3. & Percaya diri & a. & Percaya dengan kemampuan yang dimiliki menunjukkan \\
& & b. & kemampuan dengan baik \\
& & c. & Keberanian menampilkan hasil kerja kelompok \\
& & d. & Semangat dalam menyampaikan dan mempertahankan \\
& & e. & pendapat yang benar \\
& & & berinisiatif dalam memecahkan masalah \\
& & &
\end{tabular}




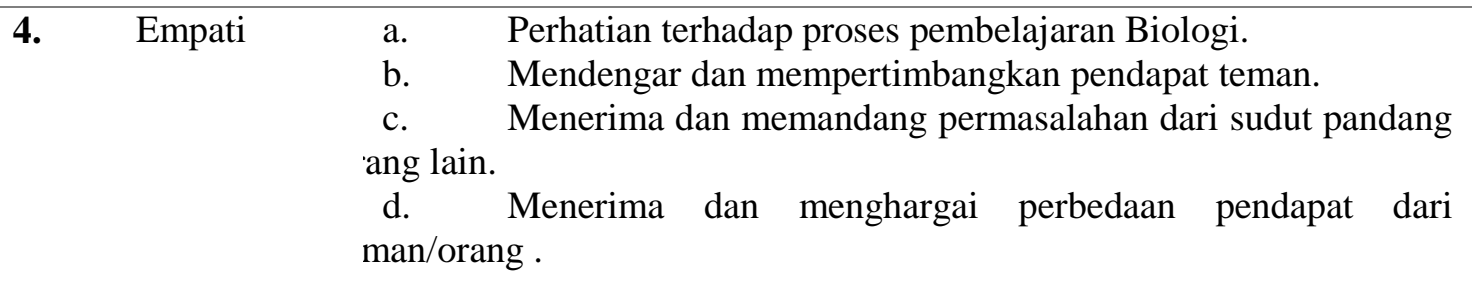

Dengan pedoman penskoran sebagai berikut: Skor 5 Jika semua deskriptor muncul, Skor 4 Jika 3 deskriptor muncul, Skor 3 Jika 2 deskriptor muncul, Skor 2 Jika 1 deskriptor muncul, dan Skor 1 Jika tidak ada deskriptor muncul. Skor 5 sangat baik, skor 4 baik, skor 3 cukup, skor 2 kurang, skor 1 sangat kurang.

Teknik pengumpulan data dalam penelitian ini berupa observasi dan tes. Tes dilakukan diakhir pertemuan Untuk mengetahui pemahaman siswa terhadap materi. Observasi dilakukan untuk mengetahui dan mengamati perkembangan kemampuan Biologi siswa dalam proses pembelajaran meliputi aspek komunikasi, kerja sama, percaya diri dan empati dalam melakukan aktivitas pembelajaran Biologi. Skor yang digunakan menggunakan skala $1-5$.

Data yang telah diperoleh dari lembar observasi pada setiap kegiatan observasi dari setiap siklus dan tes dianalisis secara deskriptif dengan menggunakan teknik persentase, untuk melihat kecenderungan yang terjadi selama proses pembelajaran. Skor kemampuan biologi setiap siswa diolah dengan mencari rata-rata skor untuk masingmasing aspek.

Tabel 2. Kriteria Skor Kemampuan Biologi dalam Proses Pembelajaran Biologi

\begin{tabular}{llll}
\hline No & Skor Rata-rata & Persentase & Kategori \\
\hline $\mathbf{1}$ & $1,00 \leq \mathrm{X}<2,00$ & $\mathrm{X}<40$ & tidak baik \\
$\mathbf{2}$ & $2,00 \leq \mathrm{X}<2,67$ & $40 \leq \mathrm{X}<53,4$ & kurang baik \\
\hline $\mathbf{3}$ & $2,67 \leq \mathrm{X}<3,33$ & $53,4 \leq \mathrm{X}<66,6$ & cukup baik \\
\hline $\mathbf{4}$ & $3,33 \leq \mathrm{X}<4,00$ & $66,6 \leq \mathrm{X}<80$ & baik \\
\hline $\mathbf{5}$ & $4,00 \leq \mathrm{X} \leq 5,00$ & $80 \leq \mathrm{X} \leq 100$ & sangat baik \\
\hline
\end{tabular}

Penelitian dilakukan pada semester ganjil tahun pelajaran 2018/2019. Subyek penelitian adalah siswa kela $\mathrm{X}$ MIPA SMAN 3 Simpang Hilir yang berjumlah 31 siswa, terdiri dari 12 laki-laki dan 19 perempuan.
Penelitian ini memiliki desain yang berupa daur spiral dengan empat langkah utama, yaitu: perencanaan, tindakan, pengamatan dan refleksi. Desain penelitian ini digambarkansebagai berikut

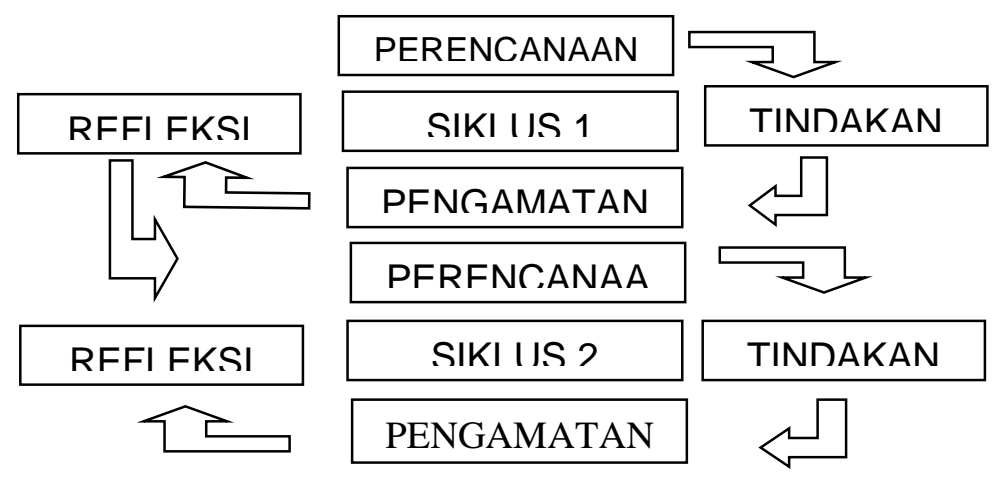

Gambar 1: Prosedur Penelitian Tindakan Kelas 


\section{Pembahasan Penelitian}

Data penelitian yang diperoleh berupa data observasi meliputi pengamatan kemampuan aspek biologi dan data tes formatif siswa setiap siklus. Data observasi digunakan untuk mengetahui pengaruh penerapan metode penemuan terbimbing dalam meningkatkan kemampuan biologi. Data tes formatif untuk mengetahui peningkatan pemahaman siswa setelah diterapkan metode penemuan terbimbing.

Siklus pertama meliputi: (1) Tahap perencanaan; tahap ini peneliti mempersiapkan perangkat pembelajaran yang terdiri dari rencana pelajaran 1 , LKS 1 , tes formatif 1 dan alat-alat pengajaran yang mendukung; (2) Tahap Kegiatan dan Pelaksanaan: Pelaksanaan kegiatan belajar mengajar untuk siklus 1 dilaksanakan pada tanggal 13 November 2018 di kelas X MIA yang terdiri 31 siswa, dalam hal ini peneliti bertindak sebagai guru. Proses belajar mengajar mengacu pada rencana pelajaran yang telah dipersiapkan. Pengamatan (observasi) dilakukan bersamaan dengan pelaksanaan belajar mengajar.

\section{Tabel 3. Rerata Keempat Aspek Kemapuan Biologi Pada Siklus 1}

\begin{tabular}{ccccc}
\hline Indikator & Komunikasi & Kerja Sama & Percaya Diri & Empati \\
\hline Rerata & 2.65 & 3,00 & 3,02 & 3,35 \\
\hline Kategori & Kurang baik & Cukup Baik & Cukup Baik & Baik \\
\hline
\end{tabular}

Berdasarkan tabel di atas aspek-aspek yang mendapatkan kriteria kurang baik adalah aspek komunikasi. Pengamatan pada siklus 1 terlihat masih banyak siswa yang kurang berani mengemukakan pendapat, merespon dan menanggapi pertanyaan, mau bertanya dan menjawab pertanyaan serta memberikan pendapat. Hanya siswa tertentu saja yang menonjol komunikasinya. Aspek kerja sama dan percaya diri reratanya cukup baik. Perlu peningkatan terutama berpartisipasi aktif melakukan diskusi dan keberanian menampilkan hasil kerja kelompok. Aspek empati sudah baik tetapi perlu peningkatan lagi. Aspek yang masih kurang baik dan cukup baik merupakan kelemahan yang terjadi pada siklus I, dan akan dijadikan bahan kajian untuk refleksi dan revisi yang akan dilakukan pada siklus II.Pemahaman biologi diperoleh dari hasil tes formatif yang dilakukan pada akhir pertemuan. Hasil dari pemahaman biologi pada siklus I dapat dilihat pada Tabel 4.

Tabel 4. Rekapitulasi Hasil Tes Formatif Siklus I

\begin{tabular}{lll}
\hline No & Uarian & Nilai Tes Siklus I \\
\hline $\mathbf{1}$ & Nilai rata-rata tes formatif & 67,32 \\
$\mathbf{2}$ & Jumlah siswa yang tuntas belajar & 8 \\
$\mathbf{3}$ & Prosentase ketuntasan siswa & $25,81 \%$ \\
\hline
\end{tabular}

Pada siklus II terdiri dari beberapa tahapan. 1) tahap perencanaan: pada tahap ini peneliti mempersiapkan perangkat pembelajaran yang terdiri dari rencana pelajaran 2, LKS 2, soal tes formatif II, dan alat-alat pengajaran yang mendukung. 2) tahap kegiatan dan pelaksanaan: pelaksanaan pada tanggal 20 November 2018 pada kelas yang sama. Dalam hal ini peneliti bertindak sebagai guru. Adapun proses belajar mengajar mengacu pada rencana pelajaran dengan memperhatikan revisi pasa siklus I, sehingga kesalahan atau kekurangan pada siklus I tidak terulang lagi pada siklus II. Pengamatan (observer) dilaksanakan bersamaan dengan pelaksanaan belajar 
mengajar. Dengan menyempurnakan aspekaspek di atas dalam penerapan metode pembelajaran penemuan terbimbing diharapkan siswa dapat menyimpulkan apa yang telah mereka pelajari dan mengemukakan pendapatnya sehingga siswa akan lebih memahami tentang apa yang telah mereka lakukan dapat disajikan. Hasil dari siklus II tentang kemampuan Biologi disajikan dalam Tabel 5 berikut.

Tabel 5. Rerata Keempat Aspek Kemapuan Biologi Pada Siklus II

\begin{tabular}{lllll}
\hline Indikator & Komunikasi & Kerja Sama & Percaya Diri & Empati \\
\hline Rerata & 3,05 & 3,34 & 3,51 & 3,45 \\
\hline Kategori & Cukup baik & Baik & Baik & Baik \\
\hline
\end{tabular}

Berdasarkan tabel diatas terlihat peningkatan secara signifikan pada ke empat aspek kemampuan Biologi antara siklus I dan siklus II. Aspek komunikasi pada siklus I reratanya 2,65 meningkat menjadi 3,05 terjadi kenaikan sebesar 0,40 poin. Aspek kerjasama dari 3,00 pada siklus I menjadi 3,34 pada siklus II, atau terjadi peningkatan 0,34 poin. Aspek percaya diri pada siklus 1 3,02 menjadi 3,51 pada siklus II, atau terjadi peningkatan 0,49 poin. Aspek empati pada siklus I 3,35 menjadi 3,45, atau terjadi peningkatan 0,1 poin. Jadi dengan penggunaan metode penemuan terbimbing kemampuan Biologi menjadi lebih baik. Hal ini berpengaruh kepada peningkatan pemahaman siswa juga meningkat. Peningkatan pemahaman ini terlihat dari perolehan tes formatif yang dilakukan pada akhir siklus II terlihat pada Tabel 6 .

\section{Tabel 6. Rekapitulasi Hasil Tes Formatif Siklus I}

\begin{tabular}{ccc}
\hline No & Uarian & Nilai Tes Siklus I \\
\hline $\mathbf{1}$ & Nilai rata-rata tes formatif & 77,65 \\
$\mathbf{2}$ & Jumlah siswa yang tuntas belajar & 24 \\
$\mathbf{3}$ & Prosentase ketuntasan siswa & $77,41 \%$ \\
\hline
\end{tabular}

Dari tabel di atas diperoleh nilai rerata tes formatif atau pengetahuan 77,65 dengan prosentase ketuntasan $77,41 \%$. Hal ini menunjukkan adanya peningkatan pengetahuan siswa dari rerata pengetahuan

\section{SIMPULAN DAN SARAN Simpulan}

Berdasarkan hasil penelitian tindakan kelas dan pembahasan yang telah diuraikan, maka dapat di simpulkan sebagai berikut: (1)Penerapan metode penemuan terbimbing meningkatkan pemahaman materi jamur pada siswa kelas X MIA SMAN 3 Simpang Hilir. Peningkatan pemahaman siswa ditandai dengan peningkatan pengetahuan dalam setiap siklus. Siklus I rerata pengetahuan 67,32 dan siklus II menjadi 77,41 .
67, 32 pada siklus I meningkat menjadi 77,65 pada siklus II. Imbasnya prosentase ketuntasan meningkat dari $25,81 \%$ meningkat menjadi $77,41 \%$.

Peningkatan pemahaman juga ditandai dengan adanya prosentase ketuntasan pada siklus I $25,81 \%$ menjadi $77,41 \%$, (2) Pembelajaran dengan metode penemuan terbimbing dalam kegiatan pembelajaran mampu meningkatkan kemampuan biologi. Dengan pembelajaran terbimbing kemampuan komunikasi, kerja sama, percaya diri dan empati meningkat secara signifikan, (3) Penerapan metode penemuan terbimbing berpengaruh positif, yaitu dapat meningkatkan minat dan motivasi belajar. Hal ini ditunjukkan dari hasil angket yang 
diberikan kepada siswa. Rata-rata siswa tertarik dan suka penggunaan metode penemuan terbimbing, sehingga mereka termotivasi untuk belajar.

\section{Saran}

Berdasarkan hasil penelitian ini, saran yang disampaikan sebagai berikut: (1) Guru sebaiknya selalu mencoba model pembelajaran yang baru dan mencoba berkreasi untuk memodifikasi model yang sudah ada sesuai dengan karakteristik siswa disekolah masing-masing. Sehingga siswa termotivasi dan terlibat aktif dalam proses pembelajaran yang diharapkan. (2) Dalam proses belajar mengajar hendaknya guru dapat melihat situasi kelas dan kondisi siswa untuk menentukan pilihan dalam penggunaan model pembelajaran yang tepat sesuai dengan materi, sehingga dapat menciptakan lingkungan belajar yang kondusif dan menyuenangkan siswa. Hal tersebut berdampak baik pada daya serap siswa terhadap materi pembelajaran. (3) Model pembelajaran penemuan terbimbing dapat dijadikan sebagai alternatif pembelajaran untuk mata pelajaran lainnya di sekolah.

\section{DAFTAR PUSTAKA}

Lie, Anita. 1995. Penemuan Terbimbing Mempraktekkan penemuan Terbimbing di Ruang-ruang Kelas. Jakarta: Grasindo.

Markaban, dkk. 2006. Model PembelajaranMatematika dengan Pendekatan Penemuan Terbimbing. Yogyakarta: Depdiknas.

Nur, Muhammad. 2000. Pembelajaran penemuan Terbimbing. Surabaya: IKIP Surabaya.

Riyanto, dkk. 2013. Pengembangan Perangkat Pembelajaran Biologi Materi

Enzim BerbasisMetode Guided Discovery Learning untuk Melatih Ketrampilan Berpikir Kritis.Surabaya: Artikel Pendidkan Pasca Sarjana Universitas Negeri Surabaya.

Roestiyah. 2001. Strategi Belajar Mengajar. Jakarta: Rineka Cipta.

Saillah. 2007. Perspektif Baru dalam Pendidikan. Bandung: FIP IKIP Bandung.

Widhiarso, Wahyu. 2009. Evaluasi Biologi dalam Pembelajaran. Yogyakarta: FIP UNY. 